\title{
Agreement between the nutritional status of schoolchildren and the perception of their guardians
}

\author{
Concordância entre o estado nutricional \\ de escolares e a percepção \\ de seus responsáveis
}

Bianca Coccaro PIVATTO ${ }^{1}$ (D) 0000-0003-4457-288X

Lena Azeredo de LIMA' (D) 0000-0002-1305-7423

\section{A B S T R A C T}

\section{Objective}

Assess the correlation between classification of nutritional status of schoolchildren and the perception of their guardians.

\section{Methods}

A cross-sectional study with children aged 6-10 years from a public school in the South of Brazil. Weight and height of the schoolchildren were collected, and the guardians answered a questionnaire containing the range of silhouettes of Brazilian children. The perception through the scale of silhouettes was compared with the actual nutritional status. Kappa coefficient was used to check the consistency of actual and perceived perception. The prevalence ratio was calculated between perceived overweight and well-nourished children.

\section{Results}

A total of 236 guardians of schoolchildren were interviewed. The level of agreement between the nutritional status assessment of actual and perceived perception was weak (Kappa $=0.32, p<0.001$ ). As for the perception of nutritional status, $50.8 \%$ of the guardians scored the nutritional rating their children correctly, of which $42.0 \%$ of these children were overweight and $60.2 \%$ were well-nourished, $p<0.05$. The prevalence of guardians who underestimated the classification of the nutritional status was $21.6 \%$, and underestimation of overweight

\footnotetext{
1 Grupo Hospitalar Conceição, Residência Multiprofissional em Saúde, Programa Saúde da Família e Comunidade. Av. Francisco Trein, 596, Cristo Redentor, 91350-200, Porto Alegre, RS, Brasil. Correspondência para/Correspondence to: BC PIVATTO. E-mail: <biancacopi@hotmail.com>.
}

Como citar este artigo/How to cite this article

Pivatto BC, Lima LA. Agreement between the nutritional status of schoolchildren and the perception of their guardians. Rev Nutr. 2018;31(2):175-81. http://dx.doi.org/10.1590/1678-98652018000200004 
children was 1.8 times greater than of well-nourished children. The overestimation of the nutritional status was $27.5 \%$. The most prevalent nutritional status was well-nourished, followed by overweight.

\section{Conclusion}

The study showed that guardians do not have the correct perception of the nutritional status of the schoolchildren. Public interventions for health education must be conducted to reduce erroneous perceptions.

Keywords: Child. Nutritional assessment. Pediatric obesity. Weight perception.

\section{RE S U M O}

\section{Objetivo}

Este artigo tem por objetivo avaliar a concordância entre a classificação do estado nutricional de escolares e a percepção dos seus responsáveis.

\section{Métodos}

Foi realizado um estudo transversal com uma amostra de crianças de seis a dez anos de idade, matriculadas em uma escola pública do Sul do Brasil. Foram coletados peso e estatura dos escolares e aplicado aos responsáveis um questionário contendo a escala de silhuetas brasileira para crianças. A percepção por meio da escala de silhuetas foi comparada com o real estado nutricional. Utilizou-se o coeficiente Kappa para verificar a concordância da percepção real e percebida. Foi calculada a razão de prevalência entre a percepção de excesso de peso e a eutrofia.

\section{Resultados}

Foram entrevistados 236 responsáveis pelos escolares. O nível de concordância entre a avaliação do estado nutricional real e percebido foi fraco (Kappa=0,32, p<0,001). Quanto à percepção do estado nutricional, 50,8\% dos responsáveis acertaram a classificação nutricional de suas crianças, sendo que $42 \%$ delas apresentavam excesso de peso e 60,2\% eram eutróficas, $p<0,05$. A prevalência de responsáveis que subestimaram a classificação do estado nutricional foi de $21,6 \%$, sendo que naquelas com excesso de peso a subestimação foi de 1,8 vez maior em relação aos eutróficos. A superestimação do estado nutricional foi de 27,5\%. 0 estado nutricional mais prevalente foi eutrofia, seguido de sobrepeso.

\section{Conclusão}

O estudo demonstrou que os responsáveis pelas crianças não tem a percepção correta do estado nutricional dos escolares. É importante realizar ações públicas de educação em saúde a fim de reduzir as percepções errôneas.

Palavras-chave: Crianças. Avaliação nutricional. Obesidade pediátrica. Percepção de peso.

\section{NTRODUCTION}

Childhood obesity is a serious public health problem throughout the world [1]. In Brazil, according to the 2008-2009 Pesquisa Orçamento Familiar (POF, Family Budget Survey), excess weight in children was observed as of the age of five years in all Brazilian regions and income groups. The prevalence of excess weight in children in the Southern region was 36.3\% for boys and $35.5 \%$ for girls, while obesity was present in $16.7 \%$ and $16.2 \%$ [2], respectively.

The high prevalence of excess weight deserves attention, since many conditions related to obesity, such as hypertension, diabetes Mellitus type 2, cardiovascular diseases, among other metabolic disorders, are found to be more frequent in children [3]. Among the risk factors for becoming obese, in addition to genetics, are family lifestyle and eating habits $[4,5]$.

Recent studies focusing on obesity prevention [6,7] have assessed the parental perception regarding the nutritional status of children. Parental perceptions of excess weight and their understanding of the health consequences are critical for the development of preventive measures or treatment of childhood obesity [6]. However, the literature suggests that parents tend to underestimate the nutritional status of children $[8,9]$. 
Thus, the aim of this study was to assess the agreement between the classification of nutritional status of schoolchildren and the perception of their guardians.

\section{METHOD S}

This cross-sectional study was carried out between June and November 2016. The study population consisted of all children aged 6-10 years enrolled in a public school in Porto Alegre, Rio Grande do Sul, in an area covered by a primary health care unit, and parents. In this study, the term 'guardian' refers to the person with some degree of parenting in relation to the child.

Guardians who presented apparent signs of cognitive impairment and were unable to answer the questionnaire and schoolchildren with physical limitations that prevented the anthropometric assessment were excluded.

The sample size was based on the study of Lundahl et al. [10], considering the universe of 407 schoolchildren from the first to the third grade of elementary school. For a 95\% confidence level, a sample of 235 children was determined to provide a parental prevalence of underestimation of excess weight of $68 \%$ with a margin of error of $6 \%$.

Data collection was carried out in two stages with the assistance of previously trained trainees and Nutrition residents. The first stage was carried out with the guardians of the children in the classroom after the trimestral examination of the students. All guardians who were invited to participate in the study signed the Informed Consent form (IC). A total of 245 individuals were selected, but only 240 accepted to participate in the study.

After agreeing and accepting to participate in the study, a questionnaire, which had been previously explained to the guardians, was applied. The questionnaire contained the scale of Brazilian silhouettes for children [11] and questions related to gender, age, degree of kinship, and schooling.

The scale in the questionnaire consisted of an instrument that uses 11 children's silhouettes, for each gender, presented in ascending order where each one represents a medium Body Mass Index (BMI). The guardians identified the image that best represented the nutritional status of their child.

The second stage of the research consisted of the anthropometric measurements of children. The measurements were taken in a classroom reserved for this purpose. A total of 236 schoolchildren participated in the study after the children signed the consent, as 4 children were not present during the nutritional assessment period.

The anthropometric measurements were measured using standardized techniques according to the World Health Organization [12]. The weight was measured using a portable electronic scale (model P150M ${ }^{\circledR}$ Lider Balanças, Araçatuba, São Paulo, Brasil), with a maximum capacity of $200 \mathrm{~kg}$; portable stadiometer (Caumaq Ltd, Cachoeira do Sul, Rio Grande do Sul, Brasil) with maximum height of $2,10 \mathrm{~m}$ was used to measure height. All equipments were duly calibrated and tested.

The data were transferred to the Anthro Plus 2007 software (World Health Organization, Geneva, Switzerland). For the classification of the nutritional status, the criteria proposed by the World Health Organization (WHO) were adopted and the Body Mass Index/Age (BMI/A) indicator was used in accordance with the Z-score [13].

The perception of the silhouette scale was compared with the actual nutritional status according to the Z-scores (WHO). Perceived weight was calculated by the mean BMI attributed to each image of the silhouette scale and the actual height of the child for the classification in Z-score of perceived BMI/Age (BMI/A) [13].

For the purpose of analysis, the classification of the nutritional status, according to the WHO, 
was grouped as follows: severe thinness and thinness as 'thinness'; and overweight and obesity and severe obesity as 'excess weight'. The following classifications were considered: Z-score $<-2$ : thinness, $\geq Z$-score -2 and $\leq Z$-score +1 : wellnourished and $>Z$-score +1 : excess weight. In addition, in this correlation the following were considered: underestimated: perceived Z-score lower than the actual one; adequate: perceived Z-score is equal to the actual one; and overestimated: perceived Z-score higher than the actual one.

Quantitative variables were described by mean and 95\% confidence intervals. To verify the agreement between the classification of the actual and perceived nutritional status, the Kappa coefficient $(K)$, classified according to Landis \& Koch [14], that proposes six categories was used: without agreement $(<0)$; poor agreement $(0$ to 0.19 ); weak (0.20 to 0.39 ); moderate $(0.40$ to 0.59 ); substantial (0.60 to 0.79 ); and quasiperfect (0.80 to 1.0$)$.

The prevalence ratio between the perception of excess weight and well-nourished was calculated. In addition, the $Z$ test for proportion comparison with Bonferroni correction was used for the classification of variables of the actual and perceived nutritional status.

Statistical analysis was performed in the Statistical Package for the Social Sciences (SPSS Inc., Chicago, Illinois, United States) version 20 program. The level of statistical significance was set at $5 \%(p<0.05)$.

The research project was submitted to the Research Ethics Committee of the Hospital Nossa Senhora da Conceição and approved on May 17, 2016, under report n 15284/2016.

\section{RE S U L T S}

A total of 236 guardians of the schoolchildren were interviewed, of which 181 (76.7\%) were female and the mean age was 36.6 years $( \pm 10.6$ years). As for the degree of kinship, 151 (64\%) were mothers, followed by 47 fathers (20\%). The characteristics of the sample of guardians are described in Table 1.

The level of agreement between the assessment of perceived and actual nutritional

Table 1. Characterization of the sample of the 236 guardians of schoolchildren from a public school in Porto Alegre, Rio Grande do Sul (2016), Brazil.

\begin{tabular}{lccc}
\hline \multirow{2}{*}{ Variable } & Guardians of schoolchildren & \\
\cline { 2 - 3 } & $\mathrm{n}$ & $\% 5 \% \mathrm{Cl}$ & \\
\hline Gender & 55 & 23.3 & $18.1-29.2$ \\
Male & 181 & 76.7 & $70.8-81.9$ \\
Female & & & \\
Kinship & 151 & 64.0 & $57.5-70.1$ \\
Mother & 47 & 20.0 & $15.0-25.6$ \\
Father & 22 & 9.3 & $5.9-13.8$ \\
Grandmother & 6 & 2.5 & $0.9-5.5$ \\
Grandfather & 10 & 4.2 & $2.1-7.7$ \\
Other & & & $11.6-21.4$ \\
Level of Education & 38 & 16.1 & $23.5-35.6$ \\
Incomplete Elementary School & 69 & 29.2 & $48.0-61.1$ \\
Complete Elementary School & 129 & 54.7 & \\
Complete High School and College degree & & & \\
\hline
\end{tabular}

Note: $\mathrm{n}$ : number of individuals; $\mathrm{Cl}$ : Confidence Interval. 
status was poor $(K=0.32),(p<0.001)$. As for the perception of the nutritional status, described in Table 2, approximately half of the guardians scored the nutritional classification of their children correctly (120 children) $50.8 \%$ ), of which $47(42.0 \%)$ presented excess weight and 71 $(60.2 \%)$ were well-nourished $(p<0.05)$.

The prevalence of guardians who underestimated the classification of the nutritional status was $51(21.6 \%)$, and underestimation of children with excess weight was 1.8 times higher (95\% Cl:1.08-3.05) than the well-nourished. Overestimation of nutritional status was 65 (27.5\%), as described in Table 2.

Of the 236 schoolchildren assessed, 121 (51.3\%) were boys and the mean age was 7.4 years ( \pm 1.0 year). The most prevalent nutritional status was well-nourished (118 children) (50\%), followed by overweight (51 children) (21.6\%) (Table 3).

\section{I SCUSSIO N}

The level of weak agreement is similar to the one that found by Friedrich et al. [15] (Kappa=0.36) when they assessed children in municipal schools in the city of Porto Alegre. A similar finding was also described by Molina et al. [16] (Kappa=0.217).

As for the prevalence of adequate perception, the results found in the present study were lower than those found by Boa Sorte et al.

Table 2. Correlation of the assessment of the actual and perceived nutritional status of the schoolchildren by their guardians. Porto Alegre, Rio Grande do Sul (2016), Brazil.

\begin{tabular}{|c|c|c|c|c|c|c|c|c|}
\hline \multirow{3}{*}{ Classification of actual nutritional status } & \multicolumn{6}{|c|}{ Classification of perceived nutritional status } & \multirow{2}{*}{\multicolumn{2}{|c|}{ Total }} \\
\hline & \multicolumn{2}{|c|}{ Underestimated } & \multicolumn{2}{|c|}{ Adequate } & \multicolumn{2}{|c|}{ Overestimated } & & \\
\hline & $\mathrm{n}$ & $\%$ & $\mathrm{n}$ & $\%$ & $\mathrm{n}$ & $\%$ & $\mathrm{n}$ & $\%$ \\
\hline Thinness & 2 & 33.3 & 2 & 33.3 & 2 & 33.3 & 6 & 100.0 \\
\hline Well-nourished & 18 & 15.3 & $71^{*}$ & 60.2 & 29 & 24.6 & 118 & 100.0 \\
\hline Excess weight & 31 & 27.7 & $47^{*}$ & 42.0 & 34 & 30.4 & 112 & 100.0 \\
\hline Total & 51 & 21.6 & 120 & 50.8 & 65 & 27.5 & 236 & 100.0 \\
\hline
\end{tabular}

Note: ${ }^{~ I n d i c a t e s ~ a ~ s t a t i s t i c a l l y ~ s i g n i f i c a n t ~ d i f f e r e n c e ~}(p<0.05)$ by the $Z$ test for proportion comparison with Bonferroni correction.

Table 3. Characterization of a sample of 236 students enrolled from a public school in Porto Alegre, Rio Grande do Sul (2016), Brazil.

\begin{tabular}{lccc}
\hline Variable & \multicolumn{2}{c}{ Students } & \multirow{2}{*}{$95 \% \mathrm{Cl}$} \\
\cline { 2 - 3 } Gender & $\mathrm{n}$ & $\%$ & \\
Male & 121 & 51.3 & $44.7-57.8$ \\
Female & 115 & 48.7 & $42.2-55.3$ \\
Nutritional status & & & \\
Severe thinness & 1 & 0.4 & $0.01-2.34$ \\
Thinness & 5 & 2.1 & $0.69-4.87$ \\
Well-nourished & 118 & 50.0 & $43.4-56.6$ \\
Overweight & 51 & 21.6 & $16.5-27.4$ \\
Obesity & 40 & 17.0 & $12.4-22.4$ \\
Severe obesity & 21 & 8.9 & $5.59-13.28$ \\
\hline
\end{tabular}

Note: $\mathrm{n}$ : number of individuals; $\mathrm{Cl}$ : Confidence Interval. 
[17], who reported that in Salvador (BA) the correct perception of mothers of the nutritional status of their children was $75.3 \%$. It is worth mentioning that other family members were included in the sample studied, although more than half were mothers.

In this study, the incorrect perception of nutritional status was classified as underestimation and overestimation. The prevalence of underestimation was higher than the one found in another similar study conducted in Brazil [17].

It was found that underestimation was 1.8 times higher for schoolchildren who presented excess weight than the well-nourished ones. Many studies suggest that parents tend to underestimate their children's body weight. Maynard et al. [18] assessed maternal perception and found that $32.0 \%$ reported that children who presented excess weight were wellnourished. In a recent meta-analysis study, in which 69 articles were assessed, it was reported that $50.7 \%$ underestimated excess weight and obesity in children [10], which was higher than that found in the study.

Among the possible causes for explaining underestimation of excess weight in children is that excess weight is related to good health and better parent caring $[6,19,20]$, although parents generally do not acknowledge overweight or obesity as a disease [20]. Furthermore, the increase in the prevalence of excess weight in childhood may also have contributed to the parents' difficulty in recognizing the nutritional status of their children [21].

Overestimation found in this study (65 children) (27.5\%) was higher than the one found by Binkin et al. [22], who assessed 37,161 children and found that only $3.2 \%$ of the mothers overestimated the nutritional status. This finding can be related to the distorted perception of body image imposed by the current beauty pattern. In the present study, it was not possible to prove this hypothesis, thus further qualitative studies are required to investigate this correlation.
Regarding the assessment of the nutritional status of schoolchildren, only half of the children were 'well-nourished' and more than one-third presented excess weight. Other studies, although they did not use the same classification criteria $[23,24]$, found similar results. This trend was reported by Batista \& Rissin [25] who described an accelerated decline in malnutrition and increase in the prevalence of overweight and obesity in the Brazilian population, thus establishing the process of nutritional transition.

The possible limitations of this study could have been the convenience sample since it was the only way to make the study feasible. The sample depended on the parents going to the school. Another possible limitation was the use of the silhouette scale, as there is no consensus in the literature about the most appropriate instrument to ass ess the perception of the nutritional status of children.

\section{CONCLUSION}

The study showed that the guardians do not have the correct perception of the nutritional status of schoolchildren. Underestimation makes it difficult to identify the risks of childhood obesity and possible treatments. Overestimation, on the other hand, may contribute to parents influencing the perception of body image of children and consequently leading to possible inappropriate eating behavior in the search for the ideal body stereotype.

Other qualitative studies should investigate overestimation since the discussion of underestimation is more common in the literature. Public interventions to promote health education are important to reduce misperceptions and educate parents about obesity and its risks. In Brazil, the participation of parents in the health education of the School Health Program should be encouraged. 


\section{CONTRIBUTORS}

BC PIVATTO and LA LIMA collaborated in the conception, design, analysis and interpretation of data.

\section{R E FER E N CE S}

1. World Health Organization. Global status report of noncommunicable diseases 2010. Geneva: WHO; 2011.

2. Instituto Brasileiro de Geografia e Estatística. Pesquisa Brasileira de Orçamento Familiar 20082009: antropometria e estado nutricional de crianças, adolescentes e adultos no Brasil. Rio de Janeiro: IBGE; 2010.

3. Seth A, Sharma R. Childhood obesity. Indian J Pediatr. 2013;80(4):309-17.

4. Onis M. Prevenção do sobrepeso e da obesidade infantis. J Pediatr. 2015;91(2):105-7.

5. Quadros FF, Gutierrez LLP, Ribeiro JL. Obesidade e fatores de risco cardiovascular em filhos de obesos: uma revisão. Sci Med. 2013;23(2):119-26.

6. Camargo AAPM, Barros Filho AA, Antonio MARGM, Giglio JS. A não percepção da obesidade pode ser um obstáculo no papel das mães de cuidar de seus filhos. Ciênc Saúde Coletiva. 2013;18(2):323-33.

7. Tompkins CL, Seablom M, Brock DW. Parental perception of child's body weight: A systematic review. J Child Fam Stud. 2015;24:1384-91.

8. Lopes L, Santos R, Pereira B, Lopes V. Maternal perceptions of children's weight status. Child Care Health Dev. 2013;39(5):728-36.

9. Francescatto C, Santos NS, Coutinho VF, Costa RF. Mothers' perceptions about the nutritional status of their overweight children: A systematic review. J Pediatr. 2014;90(4):332-43.

10. Lundahl A, Kidwell KM, Nelson TD. Parental underestimates of child weight: A meta-analysis. Pediatrics. 2014;33(3):689-703.

11. Kakeshita IS, Silva AIP, Zanatta DP, Almeida SS. Construção e fidedignidade teste-reteste de escala de figuras brasileiras para adultos e criancas. Psic Teor e Pesq. 2009;25(2):263-70

12. World Health Organization. Physical status: The use and interpretation of anthropometry. Geneva: WHO; 1995. Technical Report Series, 854.

13. World Health Organization. Multicentre Growth Reference Study Group. WHO Child Growth Standards: Length/height-for-age, weight-for-age, weight-for-length, weight-for-height and body mass index-for-age: Methods and development. Geneva: WHO; 2006.

14. Landis JR, Koch GG. The measurement of observer agreement for categorical data. Biometrics. 1977;33(1):159-74.

15. Friedrich RR, Antunes T, Schuch I. Percepção materna do estado nutricional de crianças em escolas municipais de Porto Alegre-RS. Demetra. 2016;11(1):211-23.

16. Molina MC, Faria CP, Montero P, Cade NV. Correspondence between children's nutritional status and mothers' perceptions: A population-based study. Cad Saúde Pública. 2009;25(10):2285-90.

17. Boa-Sorte N, Neri LA, Leite ME, Brito SM, Meirelles $A R$, Luduvice FB, et al. Maternal perceptions and self-perception of the nutritional status of children and adolescents from private schools. J Pediatr. 2007;83(4):349-56.

18. Maynard LM, Galuska DA, Blanck HM, Serdula MK. Maternal perceptions of weight status of children. Pediatrics. 2003;111(5Pt2):1226-31.

19. Baughcum AE, Chamberlin LA, Deeks CM, Powers SW, Whitaker RC. Maternal perceptions of overweight preschool children. Pediatrics. 2000;106(6):1380-6.

20. Tenorio AS, Cobayashi F. Obesidade infantil na percepção dos pais. Rev Paul Pediatr. 2011;29(4):634-39.

21. Campbell MW, Williams J, Hampton A, Wake M. Maternal concern and perceptions of overweight in Australian preschool-aged children. Med J Aust. 2006;184(6):274-7.

22. Binkin N, Spinelli A, Baglio G, Lamberti A. Whats is common becomes normal: The effect of obesity prevalence on maternal perception. Nutr Metab Cardiovasc Dis. 2013;23(5):410-6.

23. Reuter CP, Burgos LT, Camargo MD, Possuelo LG, Reckziegel MB, Reuter EM, et al. Prevalence of obesity and cardiovascular risk among children and adolescents in the municipality of Santa Cruz do Sul, Rio Grande do Sul. Med J. 2013;131(5):323-30.

24. Pedraza DF, Sousa CPC, Olinda RA. Concordância entre o estado nutricional aferido e o percebido pelas mães em crianças pré-escolares. Rev Paul Pediatr. 2017;35(3):289-95.

25. Batista MF, Rissin A. A transição nutricional no Brasil: tendências regionais e temporais. Cad Saúde Pública. 2003;19(1):181-191. 